\title{
BIASES ASSOCIATED WITH FOUR STREAM SUBSTRATE SAMPLERS
}

\author{
Michael K. Young \\ Wayne A. Hubert \\ Thomas A. Wesche \\ 1991 \\ Journal Article \\ WWRC-91-22
}

In

Canadian Journal of Fisheries and Aquatic Sciences

Volume 48, Number 10

\author{
Submitted by \\ Michael K. Young and Wayne A. Hubert \\ Wyoming Cooperative Fish and Wildlife \\ Research Unit \\ University of Wyoming \\ Laramie, Wyoming \\ Thomas A. Wesche \\ Wyoming Water Resources Center \\ and \\ Range Management Department \\ University of Wyoming \\ Laramie, Wyoming
}




\title{
Biases Associated with Four Stream Substrate Samplers
}

\author{
Michael K. Young ${ }^{1}$ and Wayne A. Hubert \\ U.S. Fish and Wildlife Service, Wyoming Cooperative Fish and Wildlife Research Unit, ${ }^{2}$ University of Wyoming, Laramie, WY 82071, USA
}

and Thomas A. Wesche

Department of Range Management and Wyoming Water Research Center, University of Wyoming, Laramie, WY 82071, USA

Young, M. K., W. A. Hubert, and T. A. Wesche. 1991. Biases associated with four stream substrate samplers. Can. J. Fish. Aquat. Sci. 48: 1882-1886.

\begin{abstract}
We compared samples collected from 10 substrates of various compositions with a single-probe freeze-core sampler, a triple-probe freeze-core sampler, a McNeil sampler, and a shovel. The accuracy with which these devices sampled particles larger than $50 \mathrm{~mm}$ in diameter varied; they were oversampled by the freeze-core devices, sampled in proportion to their availability by a shovel, and sampled inconsistently by the McNeil sam: pler. The geometric mean particle size and variance of single-probe freeze-core samples consistently exceeded those of samples collected with the other devices. Most sample means also exceeded the test substrate means. By excluding the proportions of particles larger than $50 \mathrm{~mm}$ in diameter in our analyses, we found that proportions of several particles sizes in samples collected by different methods differed significantly from the actual proportions in test substrates. There were few differences between the single- and triple-probe freeze-core samples or between McNeil and shovel samples. All four samplers were biased, but the McNeil sampler most frequently produced samples that approximated the true substrate composition.
\end{abstract}

Nous avons comparé des échantillons prélevés dans dix substrats de composition variable au moyen d'un échantillonneur à carottes (freeze core) à sonde unique, d'un échantillonneur à carottes (freeze core) à sonde triple, d'un échantillonneur McNeil et d'une pelle. La précision du prélèvement d'une particule ayant un diamètre supérieur à $50 \mathrm{~mm}$ a varié selon les dispositifs utilisés; ces particules étaient sur-représentées dans les prélèvements faits avec les carrotteurs, étaient échantillonnés en proportion de leur disponibilité avec la pelle, et étaient prélevés de manière inconsistante avec l'échantillonneur McNeil. La taille moyenne géométrique des particules contenues dans les échantillons du carotteur à sonde unique, ainsi que la variance, étaient constamment supérieures à celles des échantillons prélevés au moyen des autres dispositifs. La plupart des moyennes mesurées dans les échantillons dépassaient les moyennes mesurées dans le substrat d'essai. En excluant de nos analyses les proportions de particules supérieures à $50 \mathrm{~mm}$ de diamètre, nous avons constaté que les proportions de particules échantillonnées par différentes méthodes et qui appartenaient à différentes classes granulométriques, différaient de manière significative des proportions réelles de ces particules dans les substrats d'essai. Il y a avait peu de différences entre les échantillons prélevés avec l'échantillonneur à sonde simple et les échantillons prélevés avec l'échantillonneur à sonde triple, ou entre les échantillons prélevés avec la sonde McNeil et les échantillons prélevés à la pelle. Les quatre moyens d'échantillonnage comportaient une erreur systématique, mais l'échantillonneur McNeil est celui qui donnait le plus fréquemment des échantillons qui s'apparentaient assez bien à la composition réelle du substrat.

Received April 6, 1990

Accepted April 10, 1991

(JA538)
Reçu le 6 avril 1990 Accepté le 10 avril 1991
$\mathbf{F}$ isheries biologists frequently sample substrate composition in streams to assess quality for spawning by salmonids (Stowell et al. 1983) or to detect changes in composition caused by land management (Scrivener and Brownlee 1989). Usually, one of three sampling devices is used to obtain substrate samples: single-probe freeze-core samplers (Walkotten 1976), triple-probe freeze-core samplers (Everest et al. 1980), or McNeil samplers (McNeil and Ahnell 1960). Variations of all these samplers have been developed (Koski 1966; Ringler and Hall 1988). Shovels have also been used to collect substrate

\footnotetext{
${ }^{1}$ Present address: U.S. Forest Service, Rocky Mountain Forest and Range Experiment Station, 222 S. 22nd Street, Laramie, WY 82070 , USA.

${ }^{2}$ The Unit is jointly supported by the University of Wyoming, the Wyoming Game and Fish Department, and the U.,S. Fish and Wildlife Service.
}

samples (P. Carling, Freshwater Biological Association, Far Sawrey, Ambleside, Cumbria, United Kingdom, pers. comm.). Freeze-core samplers freeze interstitial water and nearby substrate to probes that have been driven into the stream bottom; the probes are then extracted with the sample attached. McNeil samplers are forced into the substrate and the material is collected by scooping it onto a rim inside the sampler. Shovels simply skim through the upper layers of the stream bottom. The insertion of all these devices disturbs the substrate before the sample is extracted.

Although each technique samples the substrate in a different way, these differences have been assumed to have little effect on the composition of the sample (Shirazi and Seim 1979). Our objectives in this study were to (1) determine whether samples that were collected from identical substrates by different techniques would have identical compositions, (2) determine whether samples that were collected from test substrates would 
duplicate the composition of those substrates, (3) assess the variation in sample composition associated with each sampler, and (4) identify the particle sizes that were undersampled or oversampled by each technique.

\section{Methods}

All tests were conducted at the Sediment Laboratory of the University of Wyoming, Department of Range Management, from 22 March to 18 April 1989. We compared samples collected with four devices: a single-probe freeze-core sampler, a triple-probe freeze-core sampler, a McNeil sampler, and a shovel.

We designed 10 test substrates for these experiments (Table 1). Substrates A-G were designed to reveal biases of the samplers for large or small particles. Substrates H-J simulated redds of different species: $\mathrm{H}$, brook trout (Salvelinus fontinalis) (M. K. Young, unpubl. data); I, Colorado River cutthroat trout (Oncorhynchus clarki pleuriticus) (Young 1989); and $\mathrm{J}$, coho salmon (O. kisutch) (K. V. Koski, National Marine Fisheries Service, Auke Bay, Alaska, unpubl. data). We took a single sample from each of eight replicates of substrates A$\mathrm{D}$ and 16 replicates of $\mathrm{E}-\mathrm{J}$ (total 128 samples). We collected four samples from test substrates $A$ and $C$ with the single-probe and triple-probe freeze-core samplers, four samples each from test substrates B and D with the McNeil sampler and shovel, and four samples with each device from the remaining six test substrates $(\mathrm{E}-\mathrm{J})$. Thus, for comparisons among the samples collected with all devices, we used only substrates E-J. For comparisons between the test substrates and the samples collected with the single-probe freeze-core device and those taken with the triple-probe device, we used substrates $\mathrm{A}, \mathrm{C}$, and E-J. Finally, for comparisons between the test substrates and samples collected with the McNeil sampler and those collected with a shovel, we used substrates B, D, and E-J.

Material was sorted on a mechanical shaker through sieves of 10 mesh sizes (millimetres): $50,25,12.5,9.5,6.3,3.35$, $1.70,0.85,0.425$, and 0.212 ; smaller particles were collected on a pan attached to the last sieve. Replicates of each substrate were made individually. The specified proportions (by weight) of each size class were mixed in a large rotating bin for $15 \mathrm{~s}$. The mixture was poured into a sampling container (plastic bucket or tray) that was later filled with enough water to submerge the mixture at least $3 \mathrm{~cm}$. Temperature was held at $18.5^{\circ} \mathrm{C}$.
Because each device collects substrate differently, we used separate sampling techniques that allowed all particle sizes to be available to each device. Substrates for both freeze-core samplers and the McNeil sampler were placed in square plastic buckets ( 20 by 20 by $35 \mathrm{~cm}$ ). Substrates for the McNeil sampler weighed $12.7 \mathrm{~kg}$ and those for the freeze-core samplers weighed $20.0 \mathrm{~kg}$ to accommodate the tendency of freeze-core samplers to collect long, relatively narrow samples (Carling and Reader 1981) and of McNeil samplers to collect shorter samples.

To obtain freeze-core samples, we drove either one or three steel probes, $50 \mathrm{~cm}$ long and $2 \mathrm{~cm}$ in diameter, to the bottom of the plastic bucket containing the test substrate. A steel template held the three probes of the triple-probe freeze-core sampler in an equilateral triangle with 5 -cm sides (Everest et al. 1980). We froze the sample to the probe(s) by injecting liquid carbon dioxide into each probe for $2 \mathrm{~min}$. We thawed each sample in a separate plastic bucket.

The diameter and length of the McNeil sampler tube were both $15 \mathrm{~cm}$. The sampler was twisted $15 \mathrm{~cm}$ deep into the substrate and all material inside the tube was placed by hand onto a retaining rim. The sampler was then lifted from the substrate, and the material on the rim was washed into a separate plastic bucket.

Test substrates for shovels weighed $10 \mathrm{~kg}$ and were placed in rectangular plastic trays $(25$ by 38 by $13 \mathrm{~cm}$ ). We inserted a pointed shovel, 21 by $28 \mathrm{~cm}$, straight down into the substrate and then lifted the sample from the tray. After allowing the sample to drain for 2-3 s, we transferred it to a plastic bucket.

All samples were dried in an electric dryer at $60^{\circ} \mathrm{C}$ for at least $72 \mathrm{~h}$. Next, we sieved the samples as previously described and weighed the amount retained on each sieve on an electronic balance. We described the composition of the samples by calculating the proportion of material retained on each sieve and by calculating the geometric mean particle size by the method of moments (Lotspeich and Everest 1981).

Some devices may not accurately sample large particles (Adams and Beschta 1980; Lotspeich and Reid 1980; Chapman et al. 1986). This inaccuracy may create problems because the presence or absence of such particles can greatly affect the relative proportions of the other size classes. To test for inconsistencies in the sampling of large particles, we regressed the proportion of particles larger than $50 \mathrm{~mm}$ in diameter in samples collected by each of the different devices with the proportion of that size in test substrates. We decided that if proportions of this particle size in samples collected by any device were

TABLE 1. Percentages of each substrate size class in test substrates. Type is the identifying. label for each test substrate.

\begin{tabular}{lrrrrrrrrrrr}
\hline \hline & \multicolumn{10}{c}{ Sieve size $(\mathrm{mm})$} \\
\cline { 2 - 13 } Type & \multicolumn{1}{c}{50} & \multicolumn{1}{c|}{25} & 12.5 & 9.5 & 6.3 & 3.35 & 1.70 & 0.85 & 0.42 & 0.21 & 0.0 \\
\hline A & 9.1 & 9.1 & 9.1 & 9.1 & 9.1 & 9.1 & 9.1 & 9.1 & 9.1 & 9.1 & 9.1 \\
B & 9.1 & 9.1 & 9.1 & 6.1 & 12.2 & 6.7 & 13.4 & 12.5 & 6.6 & 9.3 & 6.0 \\
C & 16.7 & 15.2 & 13.6 & 12.1 & 10.6 & 9.1 & 7.6 & 6.1 & 4.5 & 3.0 & 1.5 \\
D & 16.7 & 15.2 & 13.6 & 8.1 & 14.7 & 6.7 & 11.2 & 7.4 & 2.7 & 2.2 & 1.4 \\
E & 1.5 & 3.0 & 4.5 & 4.1 & 9.7 & 6.7 & 15.5 & 17.6 & 10.3 & 16.4 & 10.7 \\
F & 9.1 & 9.1 & 9.1 & 6.1 & 12.2 & 6.7 & 20.0 & 14.8 & 5.6 & 4.5 & 2.9 \\
G & 3.0 & 6.1 & 9.1 & 8.1 & 19.2 & 6.7 & 13.4 & 12.5 & 6.6 & 9.3 & 6.0 \\
H & 0.0 & 0.0 & 27.7 & 5.3 & 11.8 & 12.2 & 22.9 & 14.6 & 3.3 & 1.4 & 0.8 \\
I & 10.8 & 24.8 & 19.7 & 4.5 & 10.3 & 8.0 & 12.6 & 6.1 & 1.6 & 1.0 & 0.6 \\
J & 5.2 & 24.6 & 19.9 & 3.3 & 9.6 & 5.9 & 8.4 & 5.1 & 3.1 & 9.0 & 5.8 \\
\hline
\end{tabular}


biased, i.e. if the slope of the regression was significantly different from unity, or if the proportions were not related to those in the test substrates, i.e. if the regression was not significant, we would recalculate the proportions of the other particle sizes without this size fraction before proceeding with further analyses.

To assess the significance of differences in composition between substrate samples and test substrates, we used the Wilcoxon signed-rank test (Sokal and Rohlf 1981) to compare the proportions of each particle size. Because the proportions of different particle sizes in a single substrate were not independent (thus possibly violating a statistical assumption), we chose the conservative Bonferroni procedure (Neter et al. 1985) to produce an experiment-wide alpha of 0.1 (alpha for individual comparisons $=0.01$ ) for all nonparametric tests comparing samples with test substrates.

To assess the significance of differences among the proportions of each particle size for samples only, we used KruskalWallis two-way analysis of variance (Pimentel and Smith 1990). When this test yielded significant results, we evaluated the significance of differences between samples collected by different pairs of devices by conducting a nonparametric Tukey test (Pimentel and Smith 1990). We selected this test instead of the Bonferroni procedure because we wished to increase the power of the comparisons even though we also increased the likelihood of incorrectly rejecting the null hypothesis. For this and all remaining tests, we considered $P \leqslant 0.05$ as indicating significance.

We further assessed differences in composition between samples and test substrates by comparing their geometric mean particle sizes. We calculated arithmetic means and standard errors of the geometric mean particle sizes before conducting planned comparisons using $t$-tests (Sokal and Rohlf 1981). In contrast with our analysis of separate particle sizes, we retained particles greater than $50 \mathrm{~mm}$ in diameter for the calculation of the geometric mean particle size to demonstrate the effects of ignoring biases associated with large particles. Finally, we regressed the geometric mean particle sizes of the samples collected by different devices on the geometric mean particle sizes of the test substrates to evaluate the variability in estimates of this parameter associated with samples collected by the various devices.

\section{Results}

The proportions of particles larger than $50 \mathrm{~mm}$ in diameter in samples other than those collected by the McNeil sampler were significantly related to the proportions in the test substrates. But the slopes of the regressions for the single-probe freeze-core samples $\left(b_{1}=2.75\right)$ and triple-probe freeze-core samples $\left(b_{1}=2.28\right)$ were both significantly different from unity. Therefore, we excluded particles larger than $50 \mathrm{~mm}$ in diameter from further analyses and recalculated the proportions of the remaining sizes for comparisons of proportions of individual particle sizes.

We found significant differences in the proportions of several particle sizes between test substrates and the samples collected by the four devices (Table 2). Single-probe freeze-core samples differed most often, while McNeil and shovel samples differed least often from the test substrates. All devices undersampled particles $6.3-9.5 \mathrm{~mm}$ and those less than $0.212 \mathrm{~mm}$ in diameter. Both freeze-core samplers oversampled particles 25$50 \mathrm{~mm}$ in diameter.
TABLE 2. Comparisons of proportions of substrate retained on sieves of different sizes between the test substrates and substrate samples collected by four devices. An inequality sign indicates a significant difference (Wilcoxon signed-rank test) and whether the proportion of that size class in the samples collected with each device tended to be greater or less than the proportion of that size class in the test substrates.

\begin{tabular}{|c|c|c|c|c|}
\hline \multirow{2}{*}{$\begin{array}{c}\text { Sieve } \\
\text { size }(\mathrm{mm})\end{array}$} & \multicolumn{4}{|c|}{ Device $^{a}$} \\
\hline & FC1 & FC3 & $\mathrm{McN}$ & Shv \\
\hline 25.0 & $>$ & $>$ & & \\
\hline 12.5 & & & & \\
\hline 9.5 & & & & \\
\hline 6.3 & $<$ & $<$ & $<$ & $<$ \\
\hline 3.35 & $<$ & & $>$ & $>$ \\
\hline 1.70 & $<$ & $<$ & & \\
\hline 0.85 & $<$ & & & \\
\hline 0.425 & & & & \\
\hline 0.212 & & $>$ & & \\
\hline$<0.212$ & $<$ & $<$ & $<$ & $<$ \\
\hline
\end{tabular}

${ }^{\mathrm{a}} \mathrm{FC} 1$ and $\mathrm{FC} 3$, single-probe and triple-probe freeze-core samples, respectively; $\mathrm{McN}=$ McNeil samples; Shv = shovel samples.

TABLE 3. Comparisons of proportions of substrate retained on sieves of different sizes among substrate samples collected by four devices. An asterisk indicates that the overall distributions of a particular substrate size among samples were significantly different (Kruskal-Wallis two-way analysis of variance); an inequality sign indicates a significant difference (nonparametric Tukey test) and whether the proportion of that size class in the samples collected with the upper device tended to be greater or lesser than the proportion of that size class in samples collected with the lower device.

\begin{tabular}{ccccccc}
\hline \hline & \multicolumn{5}{c}{ Devices $^{\mathrm{a}}$} \\
\cline { 2 - 6 } size & FC1: & FC1: & FC1: & FC3: & FC3: & McN: \\
$(\mathrm{mm})$ & $\mathrm{FC3}$ & $\mathrm{McN}$ & Shv & $\mathrm{McN}$ & Shv & Shv \\
\hline $25.0^{*}$ & & & & & & \\
$12.5^{*}$ & & & & & & \\
9.5 & & & & & $<$ & \\
$6.3^{*}$ & & & $<$ & $<$ & $<$ & \\
$3.35^{*}$ & & $<$ & $<$ & $<$ & $<$ & \\
$1.70^{*}$ & & $<$ & $<$ & $<$ & $<$ \\
$0.85^{*}$ & & & & & & \\
0.425 & & & & & & \\
0.212 & & & & & $>$ \\
$<0.212^{*}$ & & & $>$ & & $>$ \\
\hline
\end{tabular}

${ }^{\mathrm{a}} \mathrm{FC} 1$ and FC3, single-probe and triple-probe freeze-core samples, respectively; $\mathrm{McN}=\mathrm{McNeil}$ samples; $\mathrm{Shv}=$ shovel samples.

Similarly, the proportions of at least one particle size collected by most of the devices differed significantly from those collected by at least one other device (Table 3). Differences between samples collected by the two types of freeze-core samplers were not significant, nor were differences between samples collected by McNeil samplers and shovels. The proportions of particles less than $0.212 \mathrm{~mm}$ in diameter were greater in freeze-core samples than in shovel samples. McNeil and shovel samples contained greater proportions of the intermediate sizes than did the freeze-core samples.

Finally, the arithmetic means of geometric mean particle sizes of samples differed significantly from the geometric mean particle sizes of several of the test substrates (Table 4). Also, 28 of the 32 sample geometric mean particle sizes exceeded those of the test substrates. The samples collected by the single- 
TABLE 4. Arithmetic means (and standard errors) of geometric mean particle sizes $(\mathrm{mm})$ of samples collected by four devices from $10 \mathrm{sub}-$ strates of varying composition. Substrate is the test substrate label and its geometric mean. An asterisk indicates a significant difference ( $t$-test) between test and sample geometric mean particle sizes at $P \leqslant 0.05$.

\begin{tabular}{ccccc}
\hline \hline \multirow{2}{*}{$\begin{array}{c}\text { Test } \\
\text { substrate }\end{array}$} & FC1 & FC3 & McN & Shv \\
\cline { 2 - 5 } A 3.6 & 14.1 & 6.8 & - & - \\
& $(8.1)$ & $(2.8)$ & & \\
B 3.9 & - & - & 5.9 & 7.0 \\
& & & $(2.3)$ & $(2.1)$ \\
C 9.9 & 23.7 & $20.9^{*}$ & - & - \\
& $(10.2)$ & $(4.3)$ & & \\
D 9.9 & - & - & 8.9 & $14.7^{*}$ \\
& & & $(1.5)$ & $(1.3)$ \\
E 1.5 & 2.7 & $2.6^{*}$ & $2.3^{*}$ & $2.3^{*}$ \\
& $(0.9)$ & $(0.4)$ & $(0.3)$ & $(0.5)$ \\
F 4.7 & $15.3^{*}$ & 7.8 & 4.3 & 6.5 \\
& $(6.2)$ & $(2.3)$ & $(1.6)$ & $(2.0)$ \\
G 3.3 & 6.2 & $4.6^{*}$ & 3.1 & 4.0 \\
& $(5.0)$ & $(0.5)$ & $(0.6)$ & $(0.5)$ \\
H 4.8 & 4.7 & 5.0 & 5.0 & 5.3 \\
& $(0.8)$ & $(0.7)$ & $(0.2)$ & $(0.5)$ \\
I 11.8 & 17.4 & 17.2 & 13.6 & 15.2 \\
& $(8.2)$ & $(4.7)$ & $(3.4)$ & $(4.5)$ \\
J 6.7 & $13.3^{*}$ & $11.6^{*}$ & 8.9 & 7.1 \\
& $(3.9)$ & $(1.9)$ & $(1.9)$ & $(1.8)$ \\
\hline
\end{tabular}

${ }^{\mathrm{a}} \mathrm{FC} 1$ and FC3; single-probe and triple-probe freeze-core samples, respectively; $\mathrm{McN}=$ McNeil samples; $\mathrm{Shv}=$ shovel samples.

probe freeze-core sampler generally had the largest and most variable geometric mean particle sizes. In contrast, geometric mean particle sizes of McNeil samples usually were comparable with those of the test substrates. Regressions between geometric mean particle sizes of samples and test substrates corroborated these findings. The coefficients of determination of the regressions between the geometric mean particle sizes of the test substrates and those of the samples collected by the single-probe freeze core device, the triple-probe freeze-core device, the McNeil sampler, and the shovel were $0.36,0.76$, 0.73 , and 0.81 , respectively.

\section{Discussion}

The composition of substrate samples collected by all devices often differed from the composition of test substrates, both in the proportions of individual particle sizes and in geometric mean particle sizes. These differences indicate inaccuracies associated with the samplers, especially with respect to the larger particles, but may also suggest problems with the sampling techniques. For example, the insertion of all samplers disturbed the substrate. Such disturbance could cause fine sediment to be displaced deeper into the stream bottom or downstream by the current and could lead to undersampling of these small particles. Field studies (Everest et al. 1982; Young et al. 1989) reported that fine sediment increased with depth in the substrate, but this could be partly attributable to infiltration associated with sampling. A related problem involves the loss of fine sediment as a sample is removed from the stream bottom. Because we sampled from standing water, we could not estimate the amount of sediment that would be detached from samples by running water. However, one could alleviate this problem by installing a portable stilling well (such as a bucket without a bottom) to surround a portion of the stream bottom and effectively eliminate flow prior to sampling (T. C. Bjornn, University of Idaho, Moscow, ID, pers. comm.).

Both freeze-core samplers, particularly the single-probe sampler, tended to oversample large particles. Only in the test substrate lacking particles larger than $25 \mathrm{~mm}$ in diameter (test substrate $\mathrm{H}$ ) did the average geometric mean particle size of the single-probe samples underestimate the geometric mean particle size of the test substrate. Adams and Beschta (1980) also reported that the single-probe freeze-core sampler was biased in favor of large particles; they hypothesized that only a small portion of a large particle needed to be frozen to the probe to be sampled. Lotspeich and Reid (1980) suggested that the triple-probe freeze-core sampler would overcome this problem, but we found that it also oversampled large particles.

We found little difference in the composition of substrate samples collected with single- or triple-probe freeze-core samplers or of samples collected with the McNeil sampler or shovel. Again, this observation conflicts with the suggestion that the triple-probe freeze-core sampler should collect less biased samples than the single-probe device (Everest et al. 1980). Differences in the samples collected by dissimilar samplers also contrast with the suggestion that freeze-core and McNeil samples were similar (Everest et al. 1980; Lotspeich and Reid 1980; Shirazi et al. 1981). However, Ringler (1970) also reported differences between freeze-core and McNeil samples.

The variability in composition of substrate samples taken by the triple-probe freeze-core sampler, McNeil sampler, and shovel was moderate, but the high variability of single-probe freeze-core samples reduces the value of this technique for field surveys (cf. Shirazi et al. 1981). For example, Adams and Beschta (1980) reported large spatial and temporal variation in the composition of stream substrates, but they did not quantify the proportion of that variation caused by their use of a single-probe freeze-core sampler. Crisp and Carling (1989), also using this device, failed to detect significant differences in substrate composition at sites before and after spawning by brown trout (Salmo trutta), yet such differences have been caused by spawning brook trout (Young et al. 1989) and brown trout (Grost 1989).

Nonetheless, freeze-core samplers, especially multiple-probe instruments (v. Platts and Penton 1980), remain useful because only these devices allow the stratification of a sample and an assessment of changes in substrate composition with depth (Everest et al. 1980). Perhaps further refinements of these devices, such as a larger spread between probes, additional probes, or longer freezing intervals, could reduce their imprecision and bias.

On the basis of the relatively low variances associated with McNeil samples, and on the frequent proximity of their geometric mean particle sizes to those of the test substrates, we consider the McNeil sampler to be the most accurate device for assessing overall substrate composition. Furthermore, this accuracy might be improved by including a suction mechanism inside the sampling tube to improve the retention of fine sediment (Koski 1966) and by enlarging the tube diameter. Shovel samples were quite similar to McNeil samples and were the only samples that accurately estimated the proportion of large particles. Because sampling with a shovel is faster and easier, we recommend further laboratory and field comparisons of these two sampling techniques. 


\section{Acknowledgements}

We thank D. Lanning for laboratory assistance, L. McDonald and R. King for statistical advice, and H. Bergman, P. Eschmeyer, F. Everest, K Koski, R. Marston, F. Rahel, and R. Wiley for reviewing the manuscript. The project was funded by the United States Forest Service, the Wyoming Game and Fish Department, and the Wyoming Water Research Center.

\section{References}

Adams, J. N., AND R. L. BeSChTA. 1980. Gravel bed composition in Oregon coastal streams. Can. J. Fish. Aquat. Sci. 37: 1514-1521.

CARling, P. A., AND N. A. Reader. 1981. A freeze-sampling technique suitable for coarse river bed-material. Sediment. Geol. 29: 233-239.

Chapman, D. W., D. E. WeitKamp, T. L. Welsh, M. B. Dell, and T. H. SCHADT. 1986. Effects of river flow on the distribution of chinook salmon redds. Trans. Am. Fish. Soc, 115: 537-547.

CRISP, D. T., AND P. A. CARLING. 1989. Observations on siting, dimensions and structure of salmonid redds. J. Fish Biol. 34: 119-134.

Everest, F. H., F. B. Lotspeich, AND W. R. MeEhan. 1982. New perspectives on sampling, analysis, and interpretation of spawning gravel quality, p. 325-333. In N. B. Armantrout [ed.] Acquisition and utilization of aquatic habitat inventory information. Western Division, American Fisheries Society, Bethesda, MD. 376 p.

Everest, F. H., C. E. MCLemore, AND J. F. Ward. 1980. An improved tritube cryogenic gravel sampler. U.S. For. Serv. Pac. Northwest For. Range Exp. Stn., Portland, OR, Res. Note PNW-350: 8 p.

Grost, R. T. 1989. A description of brown trout redds in Douglas Creek, Wyoming. M.S. thesis, University of Wyoming, Laramie, WY. 156 p.

Koski, K V. 1966. The survival of coho salmon (Oncorhynchus kisutch) from egg deposition to emergence in three Oregon coastal streams. M.S. thesis, Oregon State University, Corvallis, OR. 84 p.

LOTSPEICH, F. B., AND F. H. EvEREST. 1981. A new method for reporting and interpreting textural composition of spawning gravel. U.S. For. Serv. Pac. Northwest For. Range Exp. Stn., Portland, OR, Res. Note PNW-369: $11 \mathrm{p}$.

LotsPeICH, F. B., AND B. H. REID. 1980. Tri-tube freeze-core procedure for sampling stream gravels. Prog. Fish-Cult. 42: 96-99.
MCNEIL, W. J., AND W. H. AHNELl. 1960. Measurement of gravel composition of salmon stream beds. Fish. Res. Inst. University of Washington, Seattle, WA, Circ. 120: $7 \mathrm{p}$.

Neter, J., W. WASSERMAN, AND M. H. KUTNER. 1985. Applied linear statistical models, second edition. Irwin, Homewood, IL. 547 p.

Pimentel, R. A., AND J. D. SMith. 1990. Biostat I: a univariate statistical toolbox. Version 2.0. Sigma Soft, Placentia, CA. 392 p.

Platts, W. S., AND V. E. Penton. 1980. A new freezing technique for sampling salmonid redds. U.S. For. Serv. Intermountain For. Range Exp. Stn., Ogden, UT, Res. Pap. INT-248: 22 p.

RINGLER, N. H. 1970. Effects of logging on the spawning bed environment in two Oregon coastal streams. M.S. thesis, Oregon State University, Corvallis, OR. $96 \mathrm{p}$

RingleR, N. H., AND J. D. Hall. 1988. Vertical distribution of sediment and organic debris in coho salmon (Oncorhynchus kisutch) redds in three small Oregon streams. Can. J. Fish. Aquat. Sci. 45: 742-747.

SCRIVENER, J. C., AND M. J. BROWNLEE. 1989. Effects of forest harvesting on spawning gravel and incubation survival of chum (Oncorchynchus keta) and coho salmon $(O$. kisutch) in Carnation Creek, British Columbia. Can. J. Fish. Aquat. Sci. 46: 681-696.

ShIRAZI, M. A., AND W. K. SeIM. 1979. A stream systems evaluation: an emphasis on spawning habitat for salmonids. U.S. Environ. Protect. Agency, Corvallis, OR, EPA-600/3-79-109: 36 p.

Shirazi, M. A., W. K. SEIM, AND D. H. Lewis. 1981. Characterization of spawning gravel and stream system evaluation, p. 277-278. In Proceedings of the conference on salmon spawning gravel: a renewable resource in the Pacific Northwest? Rep. 39, Washington Water Research Center, Washington State University, Pullman, WA.

SOKaL, R. R., AND F. J. RoHLF. 1981. Biometry. 2nd ed. Freeman and Company, San Francisco, CA. 859 p.

Stowell, R., A., Espinosa, T. C. BJornn, W. S. Platts, D. C. Burns, and J. S. IRVING. 1983. Guide for predicting salmonid response to sediment yields in Idaho batholith watersheds. U.S. For. Serv. Northern and Intermountain Regions, Ogden, UT. 95 p.

WALKOTTEN, W. J. 1976. An improved technique for sampling streambed sediments. U.S. For. Serv. Pac. Northwest For. Range Exp. Stn., Portland, OR, Res. Note PNW-281: 11 p.

Young, M. K. 1989. Effect of substrate composition on the survival to emergence of Colorado River cutthroat trout and brown trout. Ph.D. dissertation, University of Wyoming, Laramie, WY. $121 \mathrm{p}$

Young, M. K., W. A. HuberT, AND T. A. Wesche. 1989. Substrate modification by spawning brook trout in a southeastern Wyoming stream. Trans. Am. Fish. Soc. 118: 379-385. 